This is a post-print version of 'Kossmann, M., \& Suchard, B. (2018). A reconstruction of the system of verb aspects in proto-Berbero-Semitic. Bulletin of the School of Oriental and African Studies, 81(1), 41-56.', originally published Campbridge University Press and available online: https://doi.org/10.1017/S0041977X17001355

\title{
A reconstruction of the system of verb aspects in proto-Berbero-Semitic
}

Several verbal forms reconstructed for proto-Semitic strongly resemble reconstructed forms in proto-Berber: compare Semitic yV-PaRRaS to Berber y-əFăRRăS, Semitic yV-PRaS to Berber y-əFRăS, and Semitic yV-PRuS and yV-PRiS to Berber y-ăFRəS. We suggest that these forms are historically related and sketch a line of development from the reconstructed meanings to their attested uses. yVPaRRaS, originally imperfective, retains that value in both Berber and Semitic. yVPRas, originally stative, gained a perfective meaning in Berber and Semitic; the stative meaning is retained in Berber, but was largely lost in Semitic. yVPRus/yVPRiS, originally perfective, retained that meaning in Semitic, merging with the newly perfective yVPRas forms; in Berber, yVPRaS completely replaced perfective yVPRuS/yVPRiS, relegating the latter to non-aspectual uses. We conclude by considering the quality of the first vowel; the alternation seen in Berber $y$-əFRăS and y-ăFRəS supports reconstructions as yiPRaS and yaPRuS/yaPRiS, conforming to the Barth-Ginsberg Law of Semitic.

\section{Introduction}

Semitic and Berber are both branches of the greater Afroasiatic language phylum (see Frajzyngier \& Shay 2012 for a recent overview). Even though their relationship is quite distant, with a time depth of at least 6,500 years between living members of the family (Kossmann 2013: 14), there are major points of similarity, especially in the structure of the verbal root and in the ablaut patterns that are used to denote aspect and diathesis. As we will try to show in this article, the system from which Berber and Semitic ablaut patterns are derived may be reconstructible. It is an open question to what extent (traces of) this system can also be found in other Afroasiatic languages; in the framework of this article, we will take an agnostic stance towards this, and describe the reconstructed system as "protoBerbero-Semitic", without claiming or denying that it should be reconstructed for Afroasiatic as a whole.

Both Semitic and Berber are characterized by a morphological system in which a large part of the verbs have a root consisting of three consonants (so-called radicals) which are combined with vocalic ablaut patterns (incl. gemination) that provide information about aspect and diathesis. In both families, phonological developments have blurred the system somewhat, especially because of the loss of certain consonants in some contexts. As a result, quite a number of attested verb roots have fewer than three radicals on the surface. For 
Semitic languages, the underlying, or historical, presence of lost radicals is generally accepted for some verb classes (see Voigt 1988 for an overview of the question). For Berber, recent developments in historical phonology have proven the existence of such consonants in certain verb types (Taine-Cheikh 2004; Kossmann 2001), while Karl-G. Prasse already showed in the 1970s that internal reconstructions using lost consonants are possible, and greatly simplify the reconstructible system (Prasse 1972-1973).

It should be noted, though, that there are also verb classes that have different radical structures, which have their own ablaut patterns, including the derived stems of Semitic and Berber. In this article, we shall restrict ourselves to the comparison of non-derived triradical structures, and leave the comparison and analysis of other structures to a later stage.

Compare the following three non-derived forms in reconstructible Berber and Semitic, each given with a 3SG:M prefix. The forms are given with a dummy root PRS for Semitic and FRS for Berber. ${ }^{1}$ Even though the root consonants only serve to clarify the abstract system, one may note that the Semitic root |prs| means 'to cut off, apportion, sever, decide' in Akkadian (CAD vol. 12 sub parāsu), while the reconstructible Berber root | frs | means 'to cut (esp. wood)' (Naït-Zerrad 2002: 638ff. sub FRS3).

\begin{tabular}{|l|l|l|}
\hline Semitic & Berber & Berber term \\
\hline yV-PRuS / yV-PRiS & $y$-ăFRəS & Aorist \\
\hline yV-PRaS & $y$-əFRăS & Perfective \\
\hline yV-PaRRaS & $y$-əFăRRăS & Imperfective \\
\hline
\end{tabular}

Table 1. Semitic and Berber ablaut forms compared

There exists a dazzling terminological variation when it comes to the naming of these forms in different languages and by different scholars. For Semitic, we will therefore simply refer to the forms according to their abstract structures. For Berber, where scholars make less use of such abstractions, we will also use the English terms given in table 1; for an overview of other terms, see Kossmann (2011: 56) and the discussion in Galand (2010).

\footnotetext{
${ }^{1}$ The choice of this verb as a grid follows conventions in Akkadian studies; the usage of the possibly cognate verb FRS in Berber can be considered an hommage to Rössler (1952).
} 
In Berber, only two short vowels can be reconstructed beyond doubt, a low vowel */ă/ and a high vowel */ə/. This is the system still found in Tuareg and in Ghadames; the contrast also surfaces in the more innovative system of Zenaga. In most Berber languages, */ă/ and */ə/ have merged, so the difference between y-ăFRəS and y-əFRăS was lost; one may note, however, that it is still reflected in verbs with a lost radical. It is possible that the original system of Berber had three short vowels, with a contrast between a high rounded and a high unrounded vowel (Prasse 1972-1973 I: 77; Kossmann 1999: 42-59), but there is only little Berber-internal evidence for this reconstruction .

Given that one reconstructed Berber short high vowel corresponds to two short high vowels in Semitic, the formal match between the three Semitic and the three Berber forms is near perfect. We assume that this is not coincidental, and that these three forms can be reconstructed for proto-Berbero-Semitic.

Both in Semitic and in Berber, a consonantal prefix is followed by a vowel. In Semitic, this vowel is considered to be part of the prefix, and its reconstruction is debated (see section 7 below); hence our rendering yV-PRuS (etc.). In Berber, on the other hand, there is no reason to detach the initial vowel from the ablaut pattern of the stem. With triradical verbs, it is found in virtually all forms, including imperatives and prefix-less forms, e.g. Aorist *ăfras! 'cut!'; *ăfras-ăn 'they cut'; Perfective *afrăs-ăn 'they cut (punctual past), they are cut (state)'; exactly these vowel patterns are still attested in Ghadames. In view of this, we render the Berber forms as y-ăFRəS (etc.). In the following discussion, this first vowel of the verb will be ignored for the time being, and will only be studied in more detail after a reconstruction of the proto-Berbero-Semitic system will have been obtained.

There are other verbal forms in Semitic and Berber which do not provide such a perfect match. These are the forms that are conjugated with suffixes only in both families, the Stative or Perfect in Semitic, and the conjugation of verbs of permanent state in Berber. For both families, the communis opinio is that these are innovative forms. The Semitic Stative/Perfect goes back to verbal adjectives that verbalized when they became conjugated with pronominal affixes (Huehnergard 1987). A very similar scenario is commonly reconstructed for the stative conjugation in Berber, which is clearly derived from noun-like stems (Galand 1980). It should be noted that the superficial similarity between the two families that both only use suffixes in these forms is not matched by similarities in vowel 
patterns. If one follows the communis opinio, as well as the lack of formal similarity, the forms in Berber and in Semitic can be considered parallel independent innovations within the families (D. Cohen 1984), which are therefore not reconstructible to the proto-BerberoSemitic stage.

Other verb forms conjugated with prefixes occur in Semitic: the Akkadian i-PtaRaS and West-Semitic forms such as yV-PRVS-a, yV-PRVS-an (etc.), and yV-PRVS-u forms. The existence of these tenses in proto-Semitic is debated, and since they lack clear cognates in Berber, ${ }^{2}$ this question falls outside the scope of this article. The possible remnants of $y \mathrm{~V}$ PRVS-u in Akkadian and its lack of transparency suggest that this form might be reconstructible for proto-Semitic (Voigt 2004). However, yV-PaRRaS occurs in both major branches of Semitic as an Imperfective and can no doubt be reconstructed as such into the proto-stage (see below). Therefore it is less likely that the original meaning of yV-PRVS-u was an imperfective too, even though it is used as such in the Central Semitic languages, that lost the $\mathrm{yV}$-PaRRaS form.

In addition, there exists a further, mysterious form in Berber, the Ghadames Future. This is a modal form that, depending on the verb type, is formally similar either to the Aorist or to the Perfective. It also has a special conjugation. Even though the chances are high that at least the conjugation is ancient (Kossmann 2000), the ablaut pattern may have undergone strong analogical influence from the Aorist and the Perfective. Moreover, the original function of this verb form is impossible to assess, as it is now limited to the syntactic context after the modal particle $d$ (equivalent to ad elsewhere, see below). In view of these uncertainties, we will not dwell upon the Ghadames Future in this article further.

Finally, there are a number of further verbal aspectual ablaut forms in Berber that are probably innovative. Some of these are clearly dialectal innovations (for an overview, see Kossmann 2012: 41-42). On the other hand, two more ablaut stems are clearly reconstructible for proto-Berber, the Negative Perfective and the Negative Imperfective. We

\footnotetext{
${ }^{2}$ Note however that there are no indications in Berber that allow us to reconstruct short vowels in word-final position. If one assumes that such vowels existed in preceding stages of Berber and were categorically lost, there is of course no way that one could determine whether Berber or its predecessor had forms similar to Semitic yV-PRVS-a and yV-PRVS-u.
} 
will not take these into account, following Kossmann (2015) in assuming that they were originally nominal forms.

The reconstruction of the proto-Afroasiatic verb has a long history, and many different proposals have been formulated (for a proposal relatively close to ours, see Diakonoff 1988: 85ff.). As far as we know, except for Rössler (1952), no one-to-one comparison between Semitic and Berber has ever been made. We hope to show that such a comparison is possible, and leads to a simple and elegant reconstruction of the earlier system. As the proposed Afroasiatic reconstructions are often based on different views than the most common reconstructions of Semitic, and are sometimes rather strained when it comes to the Berber data, we prefer not to give a full discussion of these earlier proposals, and work as if the subject were totally new.

\section{2. yV-PaRRaS / y-əFăRRăS}

The most obvious formal and functional parallel is found with the yV-PaRRaS/y-əFăRRăS form. In Semitic, this form is attested in Akkadian, Modern South Arabian, and Ethiosemitic. While the vowel between the second and third radical varies between languages and between verbs, *a is probably original here (Kouwenberg 2010: 109-112). The uses of this form in Akkadian have been studied in detail by Streck (1995). It amounts to an archetypical imperfective aspect, used for progressives, habituals, and future events; the same uses occur in Modern South Arabian (Rubin 2010: 123-124, 2014: 142-143) and Classical Ethiopic (Dillmann 1899: 153-155).

In Berber, the y-əFăRRăS form is also used for imperfectives, and the semantic domain of the form is virtually the same as in Akkadian. Only its use for future events is not found in most Berber languages, which rather use a construction with the modal partical ad. This particle is probably an innovation that does not predate the proto-Berber stage very much (see below), and in fact there are a couple of vestiges of the usage of the y-əFăRRăS form for marking the future. This is found in all contexts in Zenaga in addition to an auxiliary construction (Taine-Cheikh 2009) and in certain types of subordinated clauses in Middle Atlas varieties (Kossmann 2002: 366).

Thus, there is a perfect match, both in form and in (reconstructed) value, between Semitic yV-PaRRaS and Berber y-əFăRRăS. On the surface, it would seem evident that this form should be reconstructed for proto-Berbero-Semitic, and the idea is, of course, not new 
(Rössler 1952; Diakonoff 1988). However, both for Semitic and for Berber, it has been argued that the forms are internal innovations. In the case of Semitic, the main arguments are the widely accepted absence of the yV-PaRRaS form in West-Semitic languages such as Hebrew and Arabic, and its resemblance to a derived stem (called the D-stem in Akkadian studies and Stem II in Arabic studies), which also features gemination of the second radical. Thus, for example, Rundgren (1959) considers the imperfective value a reinterpretation of the original derivational meaning of the D-stem. One argument against reconstructing proto-Semitic yVPaRRaS lies in the formal differences between the Akkadian and the Ethiosemitic forms (Kouwenberg 2010: 117-125), especially in derived stems and quadriliteral roots. This problem does not occur in Modern South Arabian, whose reconstructible forms are very similar to those found in Akkadian. ${ }^{3}$ Thus, reflexes of a yV-PaRRaS aspectual form are securely attested in both East- and West-Semitic (Akkadian and Modern South Arabian, respectively).

In Semitic studies, the debate seems to be in a gridlock, with a small majority of researchers tending to reconstruct yV-PaRRaS as a proto-Semitic aspectual form (e.g. Kienast 2001, Lipiński 2001, Huehnergard 2006, Weninger 2011), while others follow Rundgren's lead, including such influential scholars as David Cohen (Knudsen 1984-86).

Within Berber studies, comparing the Imperfective to the Semitic forms is even less accepted, and the communis opinio is that it is an ancient derived form that has become integrated into the verbal system at a late stage (Galand 1977, 2010: 204; Chaker 1995:

\footnotetext{
${ }^{3}$ Kouwenberg's main objections against the identification of Classical Ethiopic yə-PaRRəS with Akkadian i-PaRRaS are: 1) the second stem vowel is invariably a in Ethiopic, but variable in Akkadian; and 2) Ethiopic marks the difference between the yə-PaRRəS and the yə-PRəS of the derived stems with gemination (e.g. $A_{1}$-stem yō-naggar vs. yō-ngar) or by changing the first stem vowel, while Akkadian shows an $a / i$ alternation in the second stem vowel (e.g. Š-stem u-šapras vs. u-šapris). But Modern South Arabian 1) has forms with different vowels in the second stem syllable, cf. Jibbali yəkódər < *yV-qaddur or *yV-qaddir besides yə-fékór < *yV-faqqar (Rubin 2014, pace Kouwenberg 2010: 119); and 2) shows the same alternation of the second stem vowel in the derived stems as Akkadian, cf. Mehri H-stem yə-hərkūb < *yV-harkab or *yV-harakkab vs. yə-hárkəb < *yV-harkib (Rubin 2010).
} 
231). ${ }^{4}$ The main internal linguistic reason for this is that there are two ways of constructing the Imperfective. With many stem and root shapes other than CCC, the gemination does not take place, and instead one finds a prefix $t t$-. There exists little doubt that this prefix is related to, and stems from, a derived form. This is corroborated by the fact that $t t$ - is incompatible with the causative derivation, and thus seems to have played a role in derivation (Kossmann 2002). It thus makes sense, in principle, to consider the other means of forming an Imperfective as stemming from a derivation too. If one considers the situation in more detail, this line of argumentation does not look very promising. In the first place, if the putative ancient geminate derivation was anything like its Semitic counterpart, the Dstem, it would have had a strong relationship to transitive expressions (Kouwenberg 1997). The origin of the $t t$ - prefix, on the other hand, obviously lies in a valency-decreasing derivation, which is still attested in this form in a number of Berber varieties (Kossmann 2002). Thus the two derivations underlying the Berber Imperfective would have had opposite values. A further argument against a derivational origin of the $y$-əFăRRăS form is the absence of residual forms. Unlike in Semitic, there is no such thing as a D-stem in Berber, and, moreover, there are hardly any native verbs that have the basic stem form P-RR-S; those that are found are all evidently secondary formations, e.g. denominal verbs like Ghadames nammar "to bless" from tanammert "blessing" (Lanfry 1973: 243). Even if the original derivation was lost, one would expect some lexicalized forms to be retained, and their absence suggests that no such derivation ever existed in Berber.

The main reasons that y-əFăRRăS is considered a Berber-internal innovation, however, have to do with the specific comparative and historical assumptions that the researchers adhere to. Thus David Cohen adheres to Rundgren's analysis of the Semitic forms as innovations and therefore has no reason to compare them with Berber. The case of the most influential analysis of the history of the Berber system, Galand (1977), is similar. Galand argues that the present situation of a non-aspectual Aorist and an aspectual Perfective (accompli) goes back to an earlier opposition where the Aorist expressed the imperfective aspect (inaccompli). What is now the Imperfective must therefore be an

\footnotetext{
${ }^{4}$ Prasse's opinion about this subject is not entirely clear. On the one hand, he seems to endorse a background in derivation (Prasse 1972-73: VI: 42-43), on the other hand he states that it was already part of the proto-Afroasiatic inventory (Prasse 2009: 276; with reference to the 1972-1973 passage).
} 
innovative form that took over the functions of the ancient Imperfective and ousted it into the domain of sequential and modal expressions.

Additionally, there is a typological argument: the fact that the Berber and Semitic Imperfectives are marked by gemination would be indicative of their derived, maybe even expressive, origin (Kouwenberg 1997: 36-37; similarly, it seems, Galand 2010: 203).

Whatever one may think of this argument in theory, there is no obvious reason why it should be relevant to proto-Berber or proto-Semitic. Even if the geminated forms represent an ancient expressive formation, the development into an aspectual form may have been in place already before Berber and Semitic split.

All in all, the arguments to consider the Berber Imperfective y-əFăRRăS as a Berberinternal innovation based on a derived stem are quite weak: nothing points to the previous existence of such a derived stem, and the apparent blend of two different derived stems with what would have been opposed semantics is very difficult to understand. As the form is both formally and semantically all but identical to the reconstructible Semitic form, we therefore conclude that it should be reconstructed as an aspectual form in Berbero-Semitic (and therefore also in proto-Berber).

It should be stressed that this does not solve all problems in the history of the Berber imperfective. As mentioned above, its present mophology seems to be a blend of two different processes. One process, gemination, is found with CCC verbs, and reconstructible as an original marker of the imperfective. The other process, prefixation of $t t-$, is undoubtedly borrowed from the passive or medio-passive derivation, and is found in longer stems and in a number of defective stem types. It is not entirely clear how and why this introduction took place, but one may think of phonotactic (Kossmann 2008) and morphological constraints on gemination, which would have triggered the introduction of an alternative morphological process to mark the Imperfective.

\section{3. yV-PRVS / y-VFRVS: introduction}

The forms with the basic structure yVPRVS are structurally quite different in Semitic and in Berber. In Semitic, the question whether yV-PRuS, yV-PRiS or yV-PRaS is used is largely a lexical choice: most verbs only allow for one form. In Berber, on the other hand, every verb has both a y-ăFRəS and a y-əFRăS form. Instead of being a lexical choice, the two forms constitute a fully productive opposition. 
In order to reach a reconstruction of the system behind these forms, one has to look in detail at the individual systems of the two language families, and attempt to make a family-internal reconstruction of these. While informed by the data from the other family, this reconstruction should not be dependent on them.

In Semitic, all three yV-PRVS forms are used in the same way. In Akkadian, they express perfective events in the past. This perfective meaning has largely been taken over by the suffix conjugation in West-Semitic, but yV-PRVS still occurs in this use in vestigial forms in different West-Semitic languages (Kouwenberg 2010: 129). This meaning is therefore reconstructed for the proto-Semitic YV-PRVS form (Huehnergard 2006). Besides past events, YV-PRVS and derived forms are also used to express various forms of deontic modality, and the imperative is formed from the same stem, PRVS (Suchard forthcoming). Both of these uses may be related to the perfective aspect.

The usage of the Berber y-ăFRəS and y-əFRăS forms will be discussed in the relevant sections below.

\section{4. yV-PRaS / y-əFRăS}

Let us first take a look at the forms with internal /a/: Semitic yV-PRaS and Berber y-əFRăS. In Semitic, the distribution of yV-PRaS is lexically determined. It consistently occurs with verbs that express a change of state in the subject, such as *yV-bsal 'it became cooked, it ripened' or *yV-qrab 'he came near'. Verbs with yV-PRaS forms are therefore often referred to as the 'stative' or 'intransitive' class in Semitic grammars, but the occurrence of transitive forms like *yV-Imad 'he learned' and *yV-lbas 'he put on (clothing)' makes 'middle' a better term (M. Cohen 1955).

Unusual semantics occur with forms of two irregular verbs in Akkadian, idû 'to know' and išû 'to have'. Unlike other YV-PRVS forms, these so-called prefixed statives express a present state: thus, īdé (from *yi-ydaৎ or *yi-wdaৎ) means 'he knows', not 'he came to know'; ǐšu (from *yi-ysaw or *yi-wsaw) means 'he has', not 'he acquired' (Von Soden 1995: 127). The reconstruction of the stem vowel in these verbs is uncertain, as the * $a$-vowel of ${ }^{*} y i-y / w d a \varsigma$ may be conditioned by the following pharyngeal, while išū could also go back to ${ }^{*} y i-y /$ wsuw; semantically, though, these verbs align well with the middle meaning of other yV-PRaS forms, supporting a reconstruction with ${ }^{*} a$. It may be that these frequent verbs 
preserve a stative meaning that was shared by all yV-PRaS forms at a pre-proto-Semitic stage (Kouwenberg 2010: 468).

In Berber, $y$-əFRăS is used to express a category that will be called Perfective here. The Perfective is used in two basic contexts. The first usage is the expression of a dynamic, punctual, closed event, almost always in the past. This will be called the dynamic use. The second usage is the expression of a state, without any temporal connotations. This will be called the stative use. With verbs whose semantics inherently imply processes, the stative use can be interpreted as a result of an earlier action. On the other hand, Perfectives can also be used for states that are not conceived of (nor conceivable as) results (cf. the overview in Kossmann 2012: 79ff.); thus, a verb like 'to go round, to surround' may both refer to somebody walking around an oasis (which would be dynamic), an army encircling an oasis (which would be dynamic or resultative) and to mountains surrounding it (which would be stative; cf. Kossmann 1997: 352). Many Perfective verbs in Berber are patientive ambitransitives, that is, when used dynamically, they are transitive, and the agent is the subject of the construction; when used as states, they are intransitive, and the patient of the transitive construction functions as the subject of the intransitive construction.

The analysis of the Perfective is among the most hotly debated issues in Berber linguistics. In his classic article about the uses and history of the verbal system, Lionel Galand (1977) proposed that the Perfective (accompli) is inherently dynamic, and that the stative use can be interpreted as a resultative. Although couched as synchronic, it seems that the analysis is to a large extent historical in nature, as the author concedes that verbs of permanent state are different, because they have a different history. Other writers (e.g. Chaker 1995: 63-82) have taken issue with this analysis and point to the fact that, according to native speakers' intuitions, the stative uses of the Perfective do not have a resultative connotation. The analysis as a resultative would rather be an analytical tool to reach a unified description of the Perfective than a semantic description of its uses. As these writers do not problematize the existence of other uses that are punctual and dynamic, the picture they draw is essentially one of polysemy: the Perfective has two different usages, whose meanings may be connected, but are not simply sub-parts of a larger, overarching, meaning. Finally, still other researchers take the opposite stance from Galand, and consider stative to be the quintessential meaning of the Perfective, and the dynamic uses to be either sub-uses of the stative (e.g. Prasse 2009: 237), or historical derivations from it (Mettouchi 2004). 
Most of these analyses are put forward as synchronic accounts: on the level of the languages as spoken nowadays, the Perfective is essentially dynamic (Galand) or stative (Prasse), or there is polysemy. It is, however, possible, and often silently intended, that these scenarios be rephrased in a historical way. If one takes the modern situation as largely polysemous, one may assume that one of the two meanings was derived from the other in some sort of historical process. Thus one could venture two hypotheses:

1. The Perfective was originally a punctual dynamic form. In certain contexts, it could be used as a (dynamic) resultative. From this resultative use, a new interpretation evolved, which made the process behind the resultant state less important, while the stative meaning achieved prominence. Possibly enhanced by the verbalization of verbs of permanent state, the ancient resultative evolved into a pure stative without connotations of a preceding process.

2. The Perfective was originally a marker of a state. With verbs that inherently denote a process, this entailed a resultative reading. On the basis of this resultative interpretation, the Perfective acquired a dynamic usage, which denoted the process as such, and no more just the state from which it resulted.

Both hypotheses are plausible, and no doubt attested in other language families. One notes, for instance, that the development of a stative form into a Perfective is paralleled by the West-Semitic Perfect, which stems from an ancient stative form. In order to choose between one or the other scenario, one needs external evidence.

When comparing Semitic and Berber, there are important differences and commonalities. The most important difference is that in Semitic yV-PRaS is largely a lexical class, while y-əFRăS is an aspectual stem in Berber. Thus, while most Semitic yV-PRaS verbs are not opposed to a yV-PRu/iS verb of the same stem, in Berber the opposition between $y$ əFRăS and y-ăFRəS is relevant to all verbs. The main commonality lies in the meaning. Even though middle and stative are not the same, they are semantically close; moreover, the Semitic forms *yi-ydaS and *yi-ysaw (assuming the reconstruction with $a$ is correct) could be interpreted as residual cases of a formerly more common stative meaning of the form. In this connection, it should be noted that in the earlier stages of Semitic (as attested in Akkadian), stative meanings are expressed by means of a conjugated verbal adjective (the 
so-called suffix conjugation), which is held to be a Semitic innovation. This brings us to what we consider the most plausible scenario in order to tie together the Semitic and the Berber forms. Originally, yVPRaS was a productive way to express a state; as in Berber, this included states resulting from the action described by dynamic verbs. In Semitic, a new form emerged, based on verbal adjectives, that took the place of the yV-PRaS stative. Particularly common cases of $\mathrm{yV}$-PRaS were retained, but shifted their meaning to become a perfective, e.g. *yV-Imad *'he is learnèd' > 'he learned', *yV-qrab *'he is near' > 'he came near'; crosslinguistically, such a change from a stative to a perfective - by way of an anterior or perfect, i.e. 'he has learned', 'he has come near' - is very common (Bybee et al. 1994: 63-69, 81-87). This resulted in a lexicalization of yV-PRaS: what used to be a productive opposition became a lexical feature associated with verbs that were particularly prone to a stative/intransitive reading. In Berber, on the other hand, the stative meaning was maintained. y-əFRăS did, however, acquire meanings beyond the stative, as the original resultative meaning associated with states from inherently dynamic verbs was extended to mean a simple perfective without any association to state or result.

\section{5. yV-PRuS \& yV-PRiS / y-ăFRəS}

The third set of forms that concern us here is yV-PRuS, yV-PRiS / y-ăFRəS. In Semitic, yV-PRuS and $\mathrm{yV}$-PRiS belong to the same tense as yV-PRaS. The stem vowels $-\mathrm{u}-$ and $-\mathrm{i}-$ are characteristic of transitive verbs, which only rarely have yV-PRaS forms. Based on the designation of yV-PRaS as a middle form (see above), we may refer to yV-PRuS and yV-PRiS as active. In Akkadian and Classical Arabic, yV-PRiS tends to be associated with verbs that express punctual action, like *yV-sriq 'he stole' (Aro 1964: 191). In other languages, yV-PRuS has largely replaced original yV-PRiS forms, as in Hebrew and Aramaic, or the two forms have merged phonologically, as in Ethiosemitic.

Intransitive yV-PRuS and yV-PRiS forms also occur. A class of intransitive yV-PRuS verbs is found in all classical Semitic languages; this mainly contains atelic verbs of motion, like *yV-rqud 'he skipped around', and other verbs expressing atelic activities (Aro 1964). ${ }^{5}$ In

\footnotetext{
${ }^{5}$ In Akkadian, these intransitive yV-PRuS verbs form the i-PaRRaS with - $u$ - in the second syllable of the stem, e.g. i-rappud 'he roams about' besides i-rpud 'he roamed about'. This is unlike the transitive yV-PRuS verbs, which have - $a$ - here, e.g. i-parras 'he cuts' besides i-prus 'he cut'. The atelic
} 
Akkadian, there are also adjectival verbs with yV-PRiS forms, like $i$-kbit 'it became heavy', while adjectival yV-PRuS occurs in both Akkadian, like i-tqun 'it became certain' and Arabic, like ya-kbur '(that) it be(come) great'. These verbs are usually associated with primary adjectives of the PaRiS and PaRuS patterns (Kouwenberg 2010: 60-65). In Akkadian, such adjectives form the Stative of their associated verbs, e.g. kabit 'it is heavy', taqun 'it is certain'; in West-Semitic, they have developed into Perfects, e.g. Classical Arabic kabura 'it was/became great'. It seems likely that the -i- and - $u$ - vowels in the yV-PRVS form of these verbs were taken over from the adjectives that formed the core of their paradigm.

Discounting these adjectival verbs, then, we may conclude that yV-PRiS was originally associated with transitive verbs, especially those with punctual semantics, and yV-PRuS was associated with both transitive verbs in general and atelic intransitive verbs. The main difference with yV-PRaS is that the latter is used with verbs where the subject is greatly affected, while the subjects of yV-PRiS and yV-PRuS verbs are not particularly affected. This distinction between middle $y V-P R a S$ and active $y V-P R i S$ or yV-PRuS is clearest in the cases where a middle verb coexists with an active verb from the same root, e.g. *yV-xrab it fell into ruin' vs. *yV-xrib 'he ruined'.

In Berber, $\mathrm{y}$-ăFRəS is the vowel scheme of a form commonly called the Aorist (aoriste; cf. however Prasse 1972-73, who uses imparfait). The Aorist is found in a number of welldefined contexts, and its presence is to a large degree predictable from syntactic context.

In the first place, the Aorist is used with normal imperatives and injunctives. It should be noted, however, that habitual imperatives are formed with the Imperfective. In the second place, it is found after the modal particle $a d$, which marks that the event described in the following verb is not (yet) realized. Again, it is also possible to use the Imperfective after ad for habits. ${ }^{6}$ In the third place, it is used in sequential constructions, in which the Aorist signals that a preceding earlier Mood or Aspect is still valid. The details of this construction vary between languages (Galand 1987): in some languages any aspect or mood can be continued by the Aorist (e.g. Tashelhiyt), while others have restrictions.

yV-PRuS verbs may have copied the unchanging stem vowel of other intransitive verbs, e.g. i-qarrab 'he comes near' besides i-qrab 'he came near'.

${ }^{6} \mathrm{~A}$ complicating factor is that in many varieties $\mathrm{ad}+$ Aorist can also be used for habits, a usage not without parallel in English "after dinner we would go for a walk". 
The Aorist thus has a wide range of only slightly related uses, most of which can be predicted from the syntactic context. This led Galand (1987) to the conclusion that it is best analyzed as a non-aspect, a form which has no inherent aspectual value, but which takes on the aspectual value set by its preceding context. In the case of the sequential use, this preceding context is the earlier verb form; in the case of the non-realized mode, it is the particle ad that provides the non-realized meaning. While this analysis is largely accepted by scholars working on North African varieties of Berber, it was strongly criticized by Prasse (e.g. 2009: 259ff.). Whatever one's opinion about the synchronic analysis, it is clear that the system as it stands now is not very ancient. The construction with ad is almost certainly an innovation from shortly before the proto-Berber period, ad being either an ancient pronominal form (Vycichl 1992) or an ancient conjunction (Prasse 1972-73 III: 238-239) - or both - that developed into a preverbal marker, probably in a similar way to how French developed injunctives of the type qu'il vienne 'may he come'.

All authors seem to agree that the current distribution of the Aorist is different from earlier on, and that it has been ousted from its earlier functions by innovative forms. Galand (1977) identifies this function as an ancient imperfective (inaccompli). In his view, the modern Perfective would have been more or less similar in usage to what is found today, while the $y$-əPăRRăS form would be an innovation. Once this innovation had happened, the Aorist lost most of its functions, and was left merely as a non-aspect or, if one wants, became a modal rather than an aspectual marker.

The actual uses of the Aorist - which is rather modal than aspectual, or neither - do not seem to provide many arguments to tie it to an ancient Imperfective rather than to another aspectual meaning. The main reason for Galand and his followers to consider it an ancient Imperfective seems to be the that the Perfective is already reconstructed as $y$-əFRăS, while y-əFăRRăS, the attested Imperfective, is considered an innovation; thus, in this reconstruction there is a gap at the imperfective meaning, which could be filled by the Aorist. Once one chooses different scenarios concerning the history of $y$-əFRăS and yəFăRRăS, there is no intrinsic reason to consider $y$-ăFRăS an ancient Imperfective anymore.

As argued above, we reconstruct y-əFăRRăS for proto-Berbero-Semitic, and consider $y$-əFRăS to be an ancient stative form that only later expanded to express punctual events. From this point of view, the natural locus for the Aorist would not be the Imperfective (which is already accounted for), but the Perfective. Modal usages, such as imperatives 
would be part of the Perfective meaning, which fits in well with the fact that orders typically demand a complete action and exhibit little temporal structure.

The reconstruction of the Berber Aorist y-ăFRəS as a perfective form, which included modal uses such as the imperative, conforms well with the situation in Semitic. As we saw, in proto-Semitic, yV-PRu/iS can be reconstructed as a dynamic perfective; moreover, imperatives are formed with PRVS forms. ${ }^{7}$

\section{Conclusion}

This brings us to a reconstruction of the aspectual system of proto-Berbero-Semitic. We propose that the system was built upon two axes. The first axis is DYNAMIC versus STATIVE. The second axis is PERFECTIVE versus IMPERFECTIVE. States are essentially outside the PERFECTIVE/IMPERFECTIVE opposition, and share characteristics of both: their unboundedness makes them similar to imperfectives, while the lack of internal temporal structure makes them similar to perfectives. Therefore, in a system with a dedicated stative form, one expects that the PERFECTIVE/IMPERFECTIVE opposition is only relevant to the DYNAMIC axis. Hence, we propose the following tripartite system: ${ }^{8}$

\begin{tabular}{|l|l|l|}
\hline & DYNAMIC & STATIVE \\
\hline PERFECTIVE & yVPRUS / yVPRiS & \multirow{2}{*}{ YVPRaS } \\
\cline { 1 - 2 } IMPERFECTIVE & yVPaRRaS & \\
\hline
\end{tabular}

Table 2: The proto-Berbero-Semitic verb system

In the two families, this system evolved in different manners. In Semitic, the opposition between dynamic and stative was lexicalized, no doubt as a result of the introduction of a new stative formation on the basis of conjugated verbal adjectives:

\begin{tabular}{|l|l|l|}
\hline & DYNAMIC & STATIVE \\
\hline
\end{tabular}

\footnotetext{
${ }^{7}$ As there is no aspectual difference between the different yV-PRVS forms, this is of course also true for YV-PRaS forms, even though in usage imperatives from middle verbs are less common than imperatives from active verbs.

${ }^{8}$ Note the overall similarity to the system proposed for Proto-Semitic by Diakonoff (1988:89).
} 


\begin{tabular}{|l|l|l|}
\hline PERFECTIVE & $\begin{array}{l}\text { yV-PRuS / yV-PRiS } \\
\text { / yV-PRaS }\end{array}$ & \multirow{2}{*}{ PaRVS-a } \\
\cline { 1 - 2 } IMPERFECTIVE & yV-PaRRaS & \\
\hline
\end{tabular}

Table 3: The proto-Semitic verb system

In Berber, on the other hand, the old stative acquired new functions as a marker of punctual events, and thereby jostled the old Perfective into modal and sequential uses.

\begin{tabular}{|c|c|c|}
\hline & DYNAMIC & STATIVE \\
\hline PERFECTIVE & y-əFRăS & y-əFRăS \\
\hline IMPERFECTIVE & y-əFăRRăS & \\
\hline non-aspectual & y-ăFRəS & \\
\hline
\end{tabular}

Table 4: The proto-Berber verb system

All in all, this analysis demands surprisingly few changes between proto-Berbero-Semitic and the reconstructible (and to a large extent still extant) systems of the individual families.

\section{A note on the prefix vowel}

So far, we have ignored the issue of the proto-Semitic prefix vowel, simply giving the prefixes as yV-. The reconstruction of this vowel is controversial. Several different systems are attested (see table below). In Akkadian, the prefix vowel varies per person, with a occurring in the first person singular prefix $a-$ (Old Akkadian $P a-$ ) and the second person prefix ta-, but $i$ occuring in the first person plural prefix $\mathrm{ni}^{-}$and the third person prefix $\mathrm{i}$ - (Old Akkadian $\mathrm{yi}^{\mathrm{i}}$ ). In Northwest-Semitic, one and the same prefix vowel is used for every person, but different verbs take different prefix vowels: $* a$ occurs before -PRiS and -PRuS and ${ }^{*} i$ before -PRaS (-PaRRaS not occurring in Northwest-Semitic). This distribution is commonly known as the Barth-Ginsberg Law, after its discoverers (Barth 1894: 4-6, Ginsberg 1932-1933: 382-383, 1939: 318). The Barth-Ginsberg Law also operates in some colloquial dialects of Arabic (e.g. Najdi, Ingham 1994), but Classical Arabic has $a$ as the prefix vowel in nearly all cases; Classical Ethiopic, on the other hand, has a everywhere, which must come from $* i$ or $* u$. 
Given the alternations seen in both the Akkadian and the Northwest-Semitic prefixes, this homogeneity probably results from one prefix vowel being leveled..$^{9}$

\begin{tabular}{|c|c|c|c|c|}
\hline & 1SG & $1 \mathrm{PL}$ & $2,3 F$ & $3 M$ \\
\hline Akkadian & $a-$ & $n i-$ & ta- (3F i-) & $i-$ \\
\hline $\begin{array}{l}\text { NWS } \\
\text { before -PRaS }\end{array}$ & *?i- & $*_{n i-}$ & $* t i-$ & *yi- \\
\hline NWS elsewhere & $* ? a-$ & $*^{*} n a-$ & $* t a-$ & *ya- \\
\hline Classical Arabic & $? a-$ & $n a-$ & ta- (3F:PL ya-) & $y a-$ \\
\hline Classical Ethiopic & ?ว- & na- & tə- (3F:PL уә-) & yə- \\
\hline
\end{tabular}

Table 5. The Semitic subject prefixes

Which of these distributions, if either, should be reconstructed for proto-Semitic? Barth believed the stem-based alternation to be original; more recently, this view has been defended by Testen $(1992,1994,2000)$, who invokes possible traces of the Barth-Ginsberg Law in Akkadian. Others prefer to project the Akkadian prefixes back to proto-Semitic and see the Barth-Ginsberg Law as a later innovation (Hetzron 1976, Hasselbach 2004, Huehnergard 2005). As both accounts have their advantages and difficulties, the issue has reached something of a stalemate.

If the proposed connection between proto-Semitic yV-PRaS / proto-Berber y-əFRăS and proto-Semitic yV-PRuS, yV-PRiS / proto-Berber y-ăFRəS is accepted, this provides external evidence that can resolve this question. As proto-Berber *a corresponds to protoSemitic $* i$ or $* u$ and proto-Berber $* a ̆$ corresponds to proto-Semitic $* a$, we may reconstruct the proto-Berbero-Semitic Perfective as yaPRuS and yaPRiS and the proto-Berbero-Semitic Stative as yiPRaS. This suggests that, in some prefixes at least, the Barth-Ginsberg Law was already present in proto-Berbero-Semitic, and, by extension, in proto-Semitic.

\section{References}

\footnotetext{
${ }^{9}$ The presence of $i$ in the Biblical Hebrew reflex of yV-PRuS, yiPRoS, is also often attributed to leveling, but it is more probably due to sound change (Suchard 2016).
} 
Aro, Jussi. 1964. Die Vokalisierung des Grundstammes im semitischen Verbum. Helsinki: Societas Orientalis Fennica.

Barth, Jakob. 1894. "Zur vergleichenden semitischen Grammatik". Zeitschrift der deutschen morgenländischen Gesellschaft 48, 1-21.

Bybee, Joan, Revere Perkins, and William Pagliuca. 1994. The Evolution of Grammar. Chicago (etc.): University of Chicago Press.

CAD: The Assyrian Dictionary. Chicago: Oriental Institute of the University of Chicago.

Chaker, Salem. 1995. Linguistique berbère. Études de syntaxe et de diachronie. Paris/Louvain: Peeters.

Cohen, David, 1984. La phrase nominale et l'évolution du système verbal en sémitique. Louvain/Paris: Peeters.

Cohen, Marcel, 1955. "Verbes déponents internes (ou verbes adhérents) en sémitique”, in idem, Cinquante années de recherche de recherches linguistiques, ethnographiques, sociologiques, critiques et pédagogiques, 227-247. Paris: Klincksieck.

Diakonoff, Igor. 1988. Afrasian Languages. Moscow: Nauka.

Dillmann, August. 1899. Grammatik der äthiopischen Sprache. Leipzig: Hermann Tauchnitz.

Frajzyngier, Zygmunt and Erin Shay (eds.). 2012. The Afroasiatic Languages. Cambridge etc.: Cambridge University Press.

Galand, Lionel. 1977. “Continuité et renouvellement d'un système verbal : le cas du berbère", Bulletin de la Société de Linguistique de Paris 72, 275-303.

--. 1980. "Une intégration laborieuse : les verbes de qualité en berbère", Bulletin de la Société de Linguistique de Paris 75/1, 347-362.

--. 1987. "Les emplois de l'aoriste sans particule en berbère". In Herrmann Jungraithmayr and Walter Müller (eds.), Proceedings of the Fourth International Hamito-Semitic Congress, 361-379.

--. 2010. Regards sur le berbère. Milan: Centro Studi Camito-Semitici.

Ginsberg, Harold L. 1932-1933. “On the epic of 'Al'ēyân Ba'l” [Hebrew], Tarbiz 4, 106-109, 380-390.

--. 1939. "Two religious borrowings in Ugaritic literature", Orientalia 8, 317-327.

Hasselbach, Rebecca. 2004. "The markers of person, gender, and number in the prefixes of G-preformative conjugations in Semitic", Journal of the American Oriental Society 124/1, 23-35. 
Hetzron, Robert. 1976. "Two principles of genetic reconstruction", Lingua 38, 89-108.

Huehnergard, John. 1987. "'Stative,' predicative form, pseudo-verb”, Journal of Near Eastern

Studies 46, 215-232.

--. 2005. "Features of Central Semitic", in Agustinus Gianto (ed.), Biblical and Oriental Essays in Memory of William L. Moran, 155-203. Rome: Pontificio Istituto Biblico.

--. 2006. "Proto-Semitic and Proto-Akkadian", in Guy Deutscher and N.J.C. Kouwenberg (eds.), The Akkadian language in its Semitic context, 1-18. Leiden: Nederlands Instituut for het Nabije Oosten.

Ingham, Bruce. 1994. Najdi Arabic. Amsterdam/Philadelphia: John Benjamins.

Kienast, Burkhart. 2001. Historische semitische Sprachwissenschaft. Wiesbaden: Harassowitz. Knudsen, Ebbe Egede. 1984-86. "Innovations in the Akkadian Present", Orientalia Suecana 33-35, 231-239.

Kossmann, Maarten. 1997. Grammaire du parler berbère de Figuig. Paris/Louvain: Peeters.

--. 1999. Essai sur la phonologie du proto-berbère. Cologne: Rüdiger Köppe.

--. 2000. "Le futur à Ghadamès et l'origine de la conjugaison verbale en berbère", in Salem Chaker and Andrzej Zaborski (eds.), Études berbères et chamito-sémitiques. Mélanges offerts à Karl-G. Prasse, 237-255. Paris/Louvain: Peeters.

--. 2001. "The origin of the glottal stop in Zenaga and its reflexes in the other Berber languages", Afrika und Übersee 84, 61-100.

--. 2002. "L'origine de l'aoriste intensif en berbère", Bulletin de la Société de Linguistique de Paris 97/1, 353-370.

--. 2008 "Three irregular Berber verbs: 'eat', 'drink', 'be cooked, ripen'”, in Alexander Lubotsky, Jos Schaeken and Jeroen Wiedenhof (eds.), Evidence and CounterEvidence. Essays in Honour of Frederik Kortlandt, 225-236. Amsterdam/New York: Rodopi.

--. 2011. A Grammar of Ayer Tuareg (Niger). Cologne: Rüdiger Köppe.

--. 2012. "Berber", in Zygmunt Frajzyngier and Erin Shay (eds.), The Afroasiatic Languages, 18-101. Cambridge etc.: Cambridge University Press.

--. 2013. The Arabic Influence on Northern Berber. Leiden/Boston: E.J. Brill.

--. 2015. "On the origin of the negative aspectual stems in Berber", Zeitschrift der Deutschen Morgenländischen Gesellschaft 185/2, 255-277.

Kouwenberg, N.J.C. 1997. Gemination in the Akkadian verb. Assen: Van Gorcum. 
--. 2010. The Akkadian verb and its Semitic background. Winona Lake, Indiana: Eisenbrauns. Lanfry, Jacques. 1973. Ghadamès. II. Glossaire (parler des Ayt Waziten). Algiers: Le Fichier Périodique.

Lipiński, Edward. 2001. Semitic Languages: Outline of a Comparative Grammar. 2nd edition. Louvain/Paris: Peeters.

Mettouchi, Amina. 2004. "Diathesis, aspect and stativity in Taqbaylit Berber", in Kamal NaïtZerrad, Rainer Vossen and Dymitr Ibriszimow (eds.), Nouvelles études berbères. Le verbe et autres articles, 95-110. Cologne: Rüdiger Köppe.

Naït-Zerrad, Kamal. 2002. Dictionnaire des racines berbères (formes attestées). III. D- GEY. Paris/Louvain: Peeters.

Prasse, Karl-G. 1972-1973. Manuel de grammaire touarègue. Copenhagen: Akademisk Forlag.

--. 2009. Manuel de grammaire touarègue. Syntaxe. Schwülper: Cargo Verlag.

Rössler, Otto. 1952. "Der semitische Charakter der libyschen Sprache”, Zeitschrift für Assyriologie 50, 121-150.

Rubin, Aaron. 2010. The Mehri Language of Oman. Leiden: Brill.

--. 2014. The Jibbali (Shahri) Language of Oman. Leiden: Brill.

Rundgren, Frithiof. 1959. Intensiv und Aspektkorrelation. Uppsala: Lundelquistska Bokhandeln and Wiesbaden: Harrassowitz.

Soden, Wolfram von. 1995. Grundriss der akkadischen Grammatik. 3rd edition. Rome: Pontificio Istituto Biblico.

Streck, Michael. 1995. "ittašab ibakki "weinend setzte er sich": iparras für die Vergangenheit in der akkadischen Epik", Orientalia 64/2, 33-91.

Suchard, Benjamin. 2016. The development of the Biblical Hebrew vowels. Doctoral dissertation, Leiden University.

--. Forthcoming. "A triconsonantal derivation of the lamed-he paradigm", Kleine Untersuchungen zur Sprache des Alten Testaments und seiner Umwelt.

Taine-Cheikh, Catherine. 2004. "Les verbes à finale laryngale en zénaga", in Kamal NaïtZerrad, Rainer Vossen and Dymitr Ibriszimow (eds.), Nouvelles études berbères. Le verbe et autres articles, 171-190. Cologne: Rüdiger Köppe.

--. 2009. "Les morphèmes de futur en arabe et en berbère. Réflexions pour une typologie", Faits de langues 33, 91-102. 
Testen, David. 1992. "A trace of Barth's preradical * $i$ in Akkadian", Journal of Near Eastern Studies 51, 131-133.

--. 1994. "The I-w verbal class and the reconstruction of the early Semitic preradical vocalism", Journal of the American Oriental Society 114/3, 426-434.

--. 2000. "Conjugating the 'prefixed stative' verbs of Akkadian", Journal of Near Eastern Studies 59/2, 81-92.

Voigt, Rainer. 1988. Die infirmen Verbaltypen des Arabischen und das BiradikalismusProblem. Stuttgart: Steiner.

--. 2004. "Die Entwicklung des Aspektsystems vom Ursemitischen zum Hebräischen", Zeitschrift der Deutschen Morgenländischen Gesellschaft 154, 35-55.

Vycichl, Werner. 1992. “Der Ursprung der Partikel ad- zur Bildung des Konjunktivs, des Optativs und des Futurum im Berberischen", Frankfurter Afrikanistische Blätter 4, 8285.

Weninger, Stefan. 2011. "Reconstructive morphology", in idem (ed.) The Semitic Languages, 151-178. Berlin/Boston: De Gruyter.. 